\title{
Sciendo
}

DOI: 10.1515/aon-2018-0014

\author{
LUCJAN GUCMA, KINGA DRWIĘGA, RADOSŁAW BUTRYMOWICZ
}

Maritime University of Szczecin, Poland

\section{STATISTICAL ANALYSIS OF PARAMETERS OF SELECT- ED WORLDWIDE YACHT PORTS AND MARINAS IN TERMS OF DESIGN GUIDELINES}

\begin{abstract}
In relation to the current development of the sailing, modernization and development of yacht ports and marinas are necessary. The preparations process, stages of the design, analyses and finally construction of yacht ports is time-consuming and laborious. In the article a statistical analysis of selected design parameters was described. In order to carry out the analysis a database was created based on 210 ports from different regions of the world such as: Europe, North America, Australia and South Asia. Google Earth was used to obtain the actual values of the analyzed parameters. Most of achieved results was described in the form of tables or graphs.
\end{abstract}

Keywords: statistical analysis, design guidelines, port parameters, yacht port, marina, turning basin area.

\section{INTRODUCTION}

Observed over past years growth of an interest in the sailing tourism caused the need for the development or the modernization of yacht ports and marinas. The basic purpose of the design work is to determine the minimum port parameters to ensure the highest level of safety of the vessels. In order to determine the parameters of recreational ports is necessary to define maximum dimensions of the craft that can safely navigate within the designed basin. The dimensions concern the following: the total length and breadth of the yacht, the draft and the height above the water level. When developing the spatial plan of the port, a series of data must be appoint- 
ed, these include the location of breakwaters, locks, ramps, piers, berths, mooring piles, etc. The article presents the statistical analysis of design guidelines focused on such parameters as: areas of the basin of the port, minimal lengths of the berthing line, the minimum widths of the port entrance, widths of the approach channel, widths of the fairways and minimal diameters of the turning basin. For the purpose of the analysis, a database of 210 yacht marinas from various regions all over the world was created.

\section{PARAMETERS OF YACHT PORTS AND MARINAS}

The management measures for marinas are applicable to the facilities and their associated shore-based services that support recreational boats and boats for hire [Franco, 2008]. At the beginning it is worth to mention the characteristics of yacht ports and marinas.

Marine and inland yacht ports consist of: water areas port engineering structures, port areas, buildings, technical port facilities in order to ensure the safety of moored yachts, maintenance works of yachts, recreational or tourist crafts and floating equipment. To fulfill its tasks, the yacht port must have appropriately shaped water basins sheltered from winds, waves, currents, ice as well as adequate land areas. All of the mentioned plus an adequate equipment provides professional service for yachts, their crew and for other yacht port users, as predicted in the spatial ordinances for yacht ports [Mazurkiewicz, 2010].

Marina is a yacht port including residential buildings as: pavilions or other club and port facilities providing hotel accommodation, shops, bars, cafes and restaurants and all functions required by temporary or permanent residents. Leisure centers can also be included [Mazurkiewicz, 2010].

\subsection{Basic Water Area of the Yacht Ports}

For design purposes the basic area of the yacht port equals $S_{w}=130 \mathrm{~m}^{2}$. Basic area of yacht port means area needed to allow for both: safe time alongside and all maneuvers necessary to get the yacht underway. Referring to the number of home based yachts, this area can be (in meters) calculated as follows [Mazurkiewicz, 2010]:

$$
S_{w}=130\left(N_{p}^{\prime}+N_{t}^{\prime}+N_{r}^{\prime}\right)=130\left(\frac{2}{3} N_{p}+\frac{1}{2} N_{t}+\frac{1}{5} N_{r}\right)=130\left(\frac{2}{3} N_{p}+\frac{1}{6} N_{p}+\frac{1}{50} N_{p}\right),
$$


and finally:

$$
S_{w} \cong 111 N_{p} \text { or } 78 C_{j}
$$

where:

$N_{p}$ - number of home port yachts,

$N_{r}$ - number of yacht under maintenance,

$N_{t}$ - number of visiting yachts,

$C_{j}$ - maximum number of berthing spots.

By specifying the overall size of the yacht port area, the maneuver area $S_{m}$ is also taken into account. It can be assumed that the maneuvering area is approximately equal to the basic area $S_{w}$. Guidelines of Poland found not to differ significantly from other countries (Australia, United States and Mediterranean guidelines). Wind force of 3 degrees Beaufort scale has been assumed in all data sets. The results presented

in different ways (diameter or surface) and in different units, after being reduced to the common denominator, found to be almost identical. For design purposes, a minimum radius of the maneuver area of 1.5 to $2.0 \mathrm{Lc}$ has been assumed.

\subsection{Basic Land Area of the Yacht Port $S_{1}$}

The design of marina requires careful attention to design parameters to maximize benefit, provide functional use and ensure safe berthing for yachts [Dalibor \& Prsić, 2005]. In order to determine $S_{L}$, the following areas should be determined in advance.

- Assuming that number of car parking spots equals the number of home port yachts, the minimal car park area $S_{p}$ is given by the following equation [Mazurkiewicz, 2010]:

$$
S_{p} \cong 20 N_{p} \text { or } 14 C_{j}
$$

- By specifying the minimum parking area for cars with a boat trailer $S_{t}$ and assuming that this surface must provide $50 \%$ of the cars with a boat trailer which are temporarily located in port $\left(N_{t}\right)$, and that a surface $S^{\prime}{ }_{t}=60 \mathrm{~m}^{2}$ per trailer unit is required, the following relation is given [Mazurkiewicz, 2010]:

$$
S_{t}=S^{\prime}{ }_{t} \times \frac{1}{2} N_{t}=60 \times \frac{1}{2} N_{t}=\frac{1}{6} \times 60 \times N_{p}=10 N_{p} \text { or } 7 C_{j},
$$


- Roofed parking area $S_{h}$ to home yachts during a winter season, is calculated for $1 / 3$ of number of home port yachts $\left(N_{p}\right)$ assuming average area for one yacht of $S^{\prime}{ }_{h}=60 \mathrm{~m}^{2}$ [Mazurkiewicz, 2010]:

$$
S_{h}=S_{h}^{\prime} \times \frac{1}{3} N_{p}=\frac{1}{3} \times 60 \times N_{p}=20 N_{p} \text { or } 14 C_{j}
$$

- The unit area of $S_{d}^{\prime}=175 \mathrm{~m}^{2}$ is used to indicate parking area for yachts under maintenance $S_{d}$, [Mazurkiewicz, 2010]:

$$
S_{d}=S_{d}^{\prime} \times N_{r}=175 N_{r} \cong 18 N_{p} \text { or } 12 C_{j}
$$

Taking into account listed above component areas the basic land area of the yacht port $S_{L}$ can be indicated as [Mazurkiewicz, 2010]:

$$
S_{L}=1.1 \times\left(S_{p}+S_{t}+S_{h}+S_{d}\right)=75 N_{p}
$$

or

$$
S_{L}=1.1 \times\left(14 C_{j}+7 C_{j}+14 C_{j}+12 C_{j}\right)=52 C_{j}
$$

\subsection{The Total Area of the Yacht Port $S_{J}$}

After comparing the basic water area $S_{\mathrm{w}}$ with basic land area $S_{L}$ one can note that the basic land area equals approximately 0.68 of the basic water area [Mazurkiewicz, 2010]:

$$
\begin{gathered}
S_{J}=S_{W}+S_{L}=111 N_{p}+75 N_{p}=186 N_{p} \\
\text { or } \\
S_{J}=77 C_{J}+52 C_{j}=129 C_{j}
\end{gathered}
$$

It is worth to highlight that in some countries the basic land area of yacht port equals $80 \%$ of the basic water area of yacht port, but can reach even $50 \%$. Similar relation is used in Italy: $S_{W}=55 \%, S_{L}=45 \%$. For these assumptions the following was obtained [Mazurkiewicz, 2010]: 


$$
S_{J}=1.8 \times 78 C_{j}=140 C_{j} \text { or } S_{J}=2.0 \times 78 C_{j}=156 C_{j}
$$

\subsection{The minimum width of the yacht port entrance}

The minimum width of the yacht port entrance should be between $20 \mathrm{~m}$ and 30 $\mathrm{m}$. The width depends on the maximum beam of yacht $B_{\max }$. The minimum value is set in the range of 4.5 to $6.0 B_{\max }$. [Mazurkiewicz, 2010]. For large yacht ports, the accepted width of the port entrance should be $100 \mathrm{~m}$ for the first thousands of yachts, increasing 25-30 m for every next thousands of berthing yachts. Additionally the minimum width of the entrance is to be $\left(L_{C \max }+2.0 \mathrm{~m}\right)$, where $L_{C \max }$ is total lenght of the maximum yacht provided for the port in meters.

By specifying the minimum width of the approach channel to the yacht port, it is assumed that:

It should equal to at least twice the width of its entrance,

The width (as stated bellow) should not be less than 30- $35 \mathrm{~m}$ of designed depth of channel $H_{k}$ :

$$
B_{d}=n S_{m}+2.4 B_{\max }+1.6(n-1) B_{\max }
$$

where:

$B_{d}$ - width of approach channel of designed depth $H_{k}[\mathrm{~m}]$,

$n$ - number of yachts sailing in column,

$S_{m}$ - sketch of the mast of the yacht [m],

$B_{\text {max }}$ - maximum beam of yachts allowed to navigate within approach channel $[\mathrm{m}]$.

\subsection{The minimum width of inner channels and fairways}

In order to determine the minimum width of inner channels and fairways, as stated by B. Mazurkiewicz (2010), the following conditions must be taken into account (see Fig.1):

a) Interior channel

- Minimum width : 20.0 m or $1.5 L_{C \max }$ - ( choosing higher value)

- Preferable width: $25.0 \mathrm{~m}$ or $1.75 L_{C \max }$ - ( choosing higher value)

b) Interior fairway 
- Minimum width: $1.5 L_{C \max }$

where:

- Preferable width: $1.75 L_{C \max }$

$L_{C \max }$ - maximum length of yacht allowed to enter the yacht port [m].

\subsection{The minimum average diameter of the turning basin of yacht port $D$}

When designing the turning basin, the average value is $50 \mathrm{~m}$, or $70 \mathrm{~m}$ for open 'all seasons' marinas with a large number of berthing spots. On some occasions the minimum diameter of the turning basin from $D=1.5 L_{C \max }$ up to $D=2.0 L_{C \max }$ can be accepted [Mazurkiewicz, 2010], where $L_{C \max }$ is maximum length of yacht allowed to enter the yacht port [m].

\subsection{The total length of the berthing line $L j$}

The total length of the berthing line (all wharves, piers, jetties located in the port are taken into account) depends resulting from the number of berthing spots, can be calculated by following relation [Mazurkiewicz, 2010]:

$$
L_{j} \cong 2.5 C_{j}
$$

here $C_{j}$ is maximum number of berthing spots.

The following average lengths $l_{j}$ of the berthing line for a single berthing spot is assumed as follows:

- $\quad \mathrm{l}_{\mathrm{j}}=4.0 \mathrm{~m}$, for one yacht moored perpendicularly to the jetty,

- $\mathrm{l}_{\mathrm{j}}=10.0 \mathrm{~m}$, for one yacht moored along the jetty. 


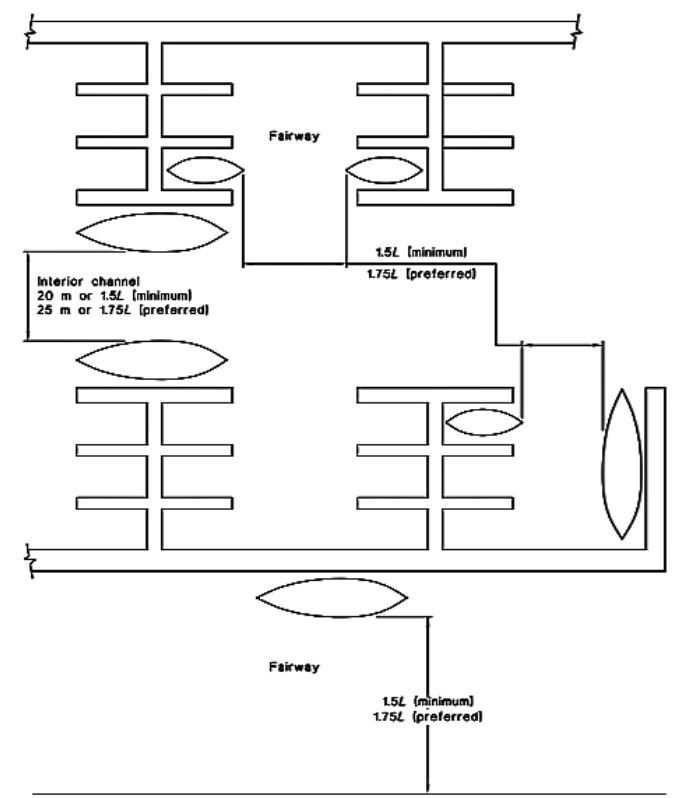

Figure 1. Minimum widths of fairways in yacht port. Source: The Australian Standards Guidelines for design of marinas.

\section{COMPARISON OF PORT GEOMETRIC CHARACTERISTICS}

Available recommendations, includes very detailed requirements for the design and execution of specific structures [Mazurkiewicz, Wiśniewski, 2008]. In order to carry out an analysis, a database based on 210 ports from different regions of world was created. The comparison analysis was performed, assuming the following three different types of ports, i.e.: open ports (from the ocean side), partially sheltered ports (from the sea side), completely sheltered (inland).

The following geometric parameters of the existing yacht ports, obtained through Google Earth, are as follows:

- length and breadth of the basin,

- area of the land part of the sailing port,

- the length of the berthing line,

- width of the port entry,

- width of internal fairways and approach channels,

- diameter of the turning basin,

- number of berths spots for yachts. 
In order to get insight into relation between the water basin area and the land area of yacht ports and marinas, the length and breadth of the two component surfaces were measured in all 210 cases considered for the analysis. The measured basin area was reduced to the lowest common denominator and stated as the average value for the given division of ports. The perfect recommended design proportion between the water basin area and the land area of yacht port is $45 \%$ up to $55 \%$.

The research indicated (Fig. 2) that this proportion stays in accordance with the are ports completely sheltered. It should be emphasized that it isn't possible to rule marinas out of the group of the entirely shielded ports, which differ significantly from this value (analogous to the results of open and partially sheltered waters).

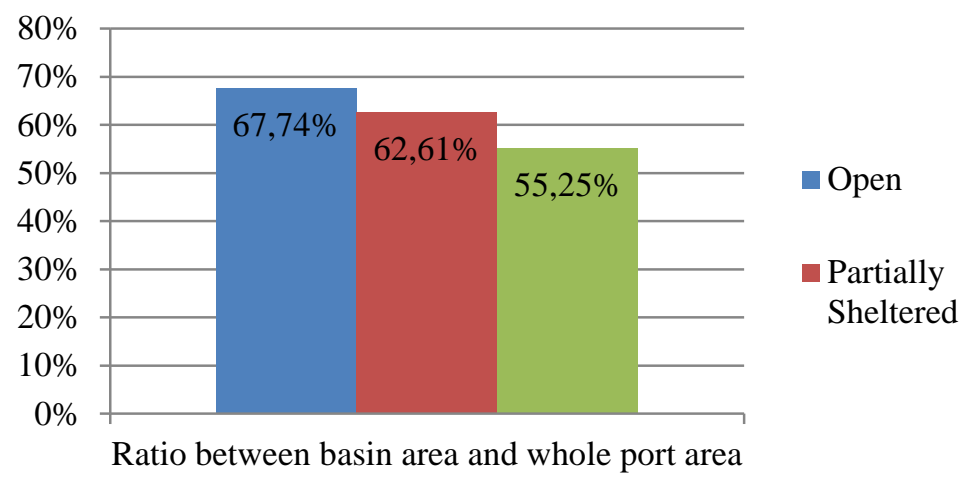

Figure 2. The ratio between the water basin area to the total area of yacht port. Source: Authors.

Consideration of the maximum quantity of yachts allowed to enter the port is the next point of the comparative analysis. In order to carry out this part of analysis, all the berthing spots in the marina in the marinas were counted, and the results were used to compute the water basin area of yacht port, $S_{w}$, according to the design guideline given in Eq.(2).

Table. 1. Comparison between the average design and real values of yacht ports.

\begin{tabular}{|l|c|c|}
\hline \multicolumn{1}{|c|}{ TYPE OF YACHT BASIN } & $\begin{array}{c}\text { AVERAGE } \\
\text { RECOMMENDED } \\
\text { DESIGN VALUE } \\
\text { [thousand } \mathrm{m}^{2} \text { ] }\end{array}$ & $\begin{array}{c}\text { AVERAGE } \\
\text { REAL VALUE } \\
\text { [thousand } \mathrm{m}^{2} \text { ] }\end{array}$ \\
\hline OPEN & 85,4 & 79,5 \\
\hline PARTIALLY SHIELDED & 74,5 & 134,9 \\
\hline COMPLETELY SHELTERED & 70,8 & 111,46 \\
\hline
\end{tabular}

Source: Authors. 


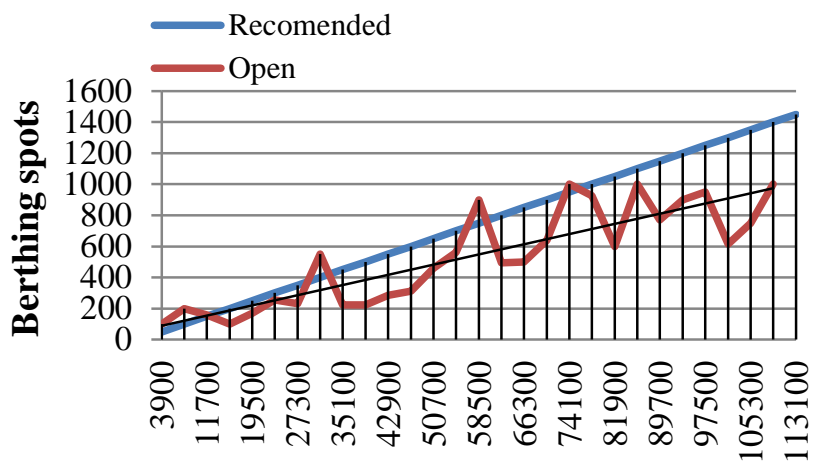

Recomended area

Figure 3.1. The ratio between basin area and number of berthing spots for open ports.

Source: Authors.

From graphs presented in figs. 3.1 to 3.3 decreasing tendencies are noticeable. The port is more sheltered, the surface area is smaller and the port is designed for fewer vessels. The table below shows the results of comparison the ratio of actual water area of a port to one craft.

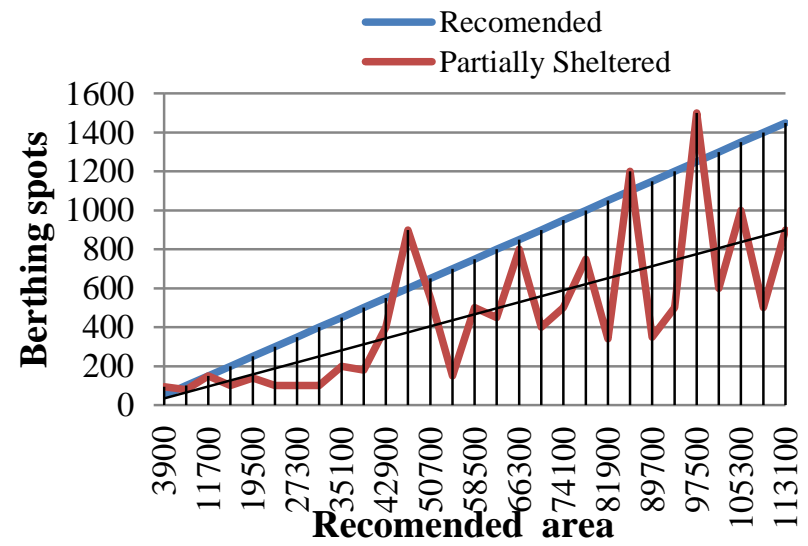

Figure 3.2. The ratio between basin area and number of berthing spots for partially sheltered ports. Source: Authors. 


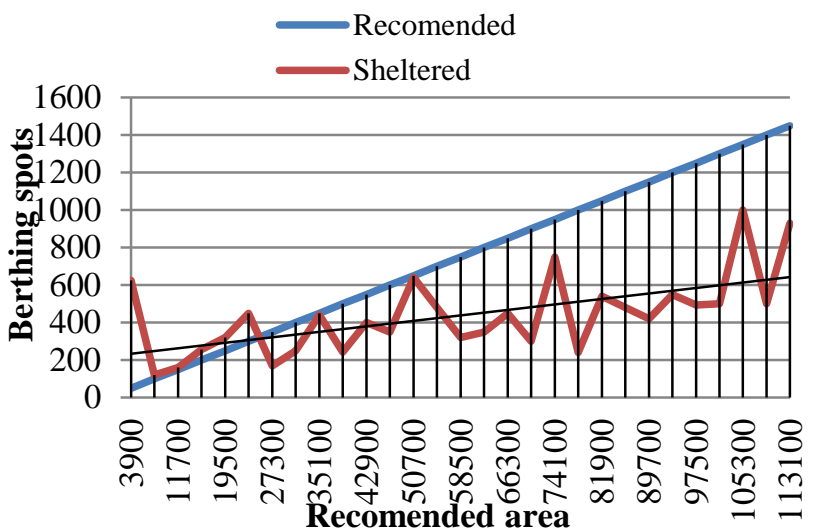

Figure 3.3. The ratio between basin area and number of berthing spots for sheltered ports. Source: Authors.

Table. 2. Comparison between the water basin area and the single yacht.

\begin{tabular}{|c|c|c|}
\hline TYPE OF YACHT BASIN & $\begin{array}{c}\text { AVERAGE RECOMMENDED } \\
\text { VALUE }[\mathrm{m}]\end{array}$ & $\begin{array}{c}\text { REAL VALUE } \\
{[\mathrm{m}]}\end{array}$ \\
\hline OPEN & $60-100$ & 101,9 \\
\hline PARTIALLY SHIELDED & $60-100$ & 78,1 \\
\hline COMPLETELY SHELTERED & $60-100$ & 72,6 \\
\hline
\end{tabular}

Source: Authors.

When designing yacht ports, the parameters of the maximum yacht capable of navigating safely within the port limits are also determined. By analyzing the ratio of the maximum values of the width of the entrance to the width of the yacht (Fig. 4), deviations in all types of surveyed waters were noted. Recommended design data of minimum $30 \mathrm{~m}$ found not to be fulfilled in most cases.

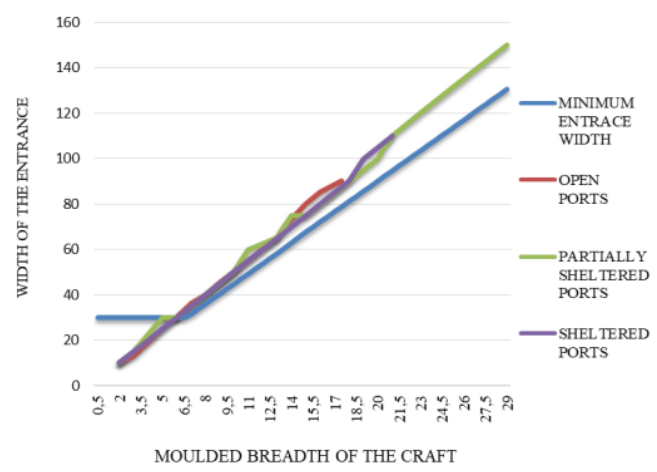

Figure 4. Comparison between the width of the entrance to the maximum beam of the yacht. Source: Authors. 
The comparison of the turning basin to the length of the maximum vessel able to safely navigate within port limits was the next analyzed parameter. Yacht ports with an outer turning basin were not taken into account for the analysis. By analyzing the actual values from the investigated ports indicates that, in all three considered types of ports, the diameter of the turning basin was larger than the recommended value of $1.5 \mathrm{~L}_{\max }$. Only occasionally it was smaller, but still above $1.2 \mathrm{~L}_{\max }$.

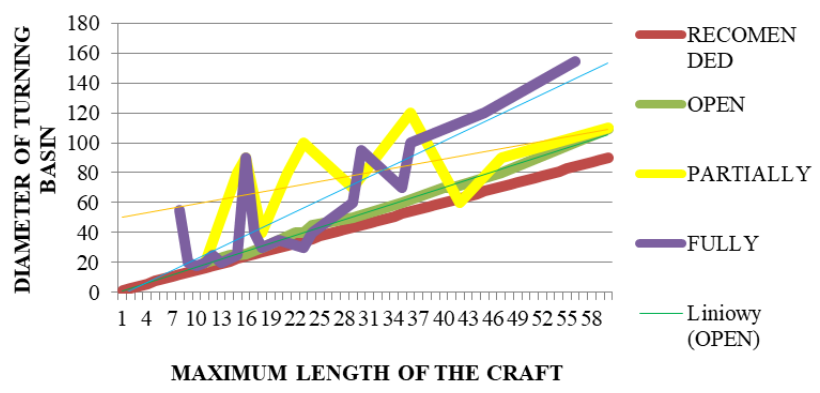

Fig.5. Comparison between the diameter of turning basin to maximum length of the craft. Source: Authors.

Considering the relation between the length of the berthing line and the number of berthing spots, one can conclude that the more sheltered the port is, the less space for one yacht is. In most ports, the length of the berthing line is shorter than the minimum value $2.5 \mathrm{Cj}$. Thanks the analysis bellow it can be noted that some port facilities are not properly designed for a good yacht service.

\section{CONCLUSIONS}

Using the Google Earth program, a special database was created for the purpose of the analyses described in the paper. The database consists of several geometric characteristics where the real values thereof were collected from 210 yacht ports from different regions all over the world. All yacht ports were divided into main groups, i.e.: open ports (from the ocean side), partially sheltered ports (from the sea side) and completely sheltered (inland). Summarizing the results obtained, you can come to the following conclusions. More the basin is sheltered, the port area is smaller, so port is designed for less number of visiting yachts. Only in ports designed for small crafts, the minimum widths of approach channel do not exceed the recommended 30 meters. Similar findings have been made in the analysis of the width of internal fairways. Most of turn basins found to be not less than recommended design size of $\min 1,5 \mathrm{~L}_{\max }$. Only in occasional cases, the width of the turn 
basin found to have smaller value, but never less than $1.2 \mathrm{~L}_{\max }$ allowing for freely rotation even the largest designated yachts. By analyzing the ratio between the length of the berthing line and the berthing spots it has been noted the port is more sheltered the less maneuvering area for single craft. In most ports, the length of the berthing line found to be less than the minimum value $2.5 \mathrm{Cj}$. Some of berthed yachts sticks out berthing spot, therefore directly reduce the width of the approach channels. To summarize results of the listed above analyses, in order to ensure safe navigation, it is necessary to continually upgrade the design data and existing yacht ports and marinas.

\section{REFERENCES}

[1] American Society of Civil Engineers (1994). Planning and Design Guidelines for Small Craft Harbours, New York.

[2] California Department of Boating and Waterways, (2005). Layout \& Design Guidelines for Marina Berthing Facilities. California.

[3] Dalibor, C., Prsić, M. (2005). Yachts Parameters for Marina Design. 19th International Symposium on Water Management and Hydraulic Engineering. Austria.

[4] Franco L. (2008). New design criteria and applications for yacht harbors. Dubai.

[5] Gucma, S. (2001). Sea Traffic Engineering (in Polish). Okrętownictwo i Żegluga, Gdańsk.

[6] Mazurkiewicz, B.(2010). Yacht Ports and Marinas. The designing (in Polish) 2nd ed. Fundacja Promocji POiGM, Gdańsk.

[7] Mazurkiewicz B., Wiśniewski F. (2008). Sea Hydrotechnical Buildings, Recommendations to the designing and the realization (in Polish). Fundacja Promocji POiGM, Gdańsk.

[8] NSW Maritime Authority, (2000). Depths in Berths and Fairways. Sydney.

[9] NSW Maritime Authority, (2001). The Australian Standards Guidelines for design of marinas. Sydney.

Received October 2018

Reviewed December 2018

Accepted December 2018 


\section{LUCJAN GUCMA}

Maritime University of Szczecin

Wały Chrobrego 1-2, 70-500 Szczecin, Poland

e-mail: 1.gucma@am.szczecin.pl

\section{KINGA DRWIĘGA}

Maritime University of Szczecin

Wały Chrobrego 1-2, 70-500 Szczecin, Poland

e-mail: k.drwiega@am.szczecin.pl

\section{RADOSŁAW BUTRYMOWICZ}

Maritime University of Szczecin

Wały Chrobrego 1-2, 70-500 Szczecin, Poland

e-mail: r.butrymowicz@am.szczecin.pl

\section{STRESZCZENIE}

W związku z bieżącym rozwojem żeglarstwa, konieczna jest modernizacja oraz rozwój portów jachtowych i marin jachtowych. Proces przygotowania, etapy projektowania, analizy i wreszcie budowa portów jachtowych jest czasochłonna oraz pracochłonna. W artykule opisano statystyczną analizę wybranych parametrów projektowych. W celu przeprowadzenia analizy stworzono bazę danych opartą na 210 portach z różnych regionów świata, np: Europa, Ameryka Północna, Australia i Azja Południowa. Do uzyskania rzeczywistych wartości analizowanych parametrów wykorzystano Google Earth. Większość uzyskanych wyników została opisana w formie tabel lub wykresów. 